\title{
Array CGH in patients with learning disability (mental retardation) and congenital anomalies: updated systematic review and meta-analysis of 19 studies and 13,926 subjects
}

\author{
Gurdeep S. Sagoo, MSc, PhD ${ }^{I}$, Adam S. Butterworth, BA, MSc ${ }^{2}$, Simon Sanderson, MRCP, FFPH ${ }^{3}$, \\ Charles Shaw-Smith, MA, PhD ${ }^{4}$, Julian P. T. Higgins, BA, PhD ${ }^{1}$, and Hilary Burton, MA, FFPH ${ }^{3}$
}

\begin{abstract}
Array-based comparative genomic hybridization is being increasingly used in patients with learning disability (mental retardation) and congenital anomalies. In this article, we update our previous meta-analysis evaluating the diagnostic and false-positive yields of this technology. An updated systematic review and meta-analysis was conducted investigating patients with learning disability and congenital anomalies in whom conventional cytogenetic analyses have proven negative. Nineteen studies (13,926 patients) were included of which 12 studies (13,464 patients) were published since our previous analysis. The overall diagnostic yield of causal abnormalities was 10\% $(95 \%$ confidence interval: $8-12 \%)$. The overall number needed to test to identify an extra causal abnormality was $10(95 \%$ confidence interval: $8-13)$. The overall false-positive yield of noncausal abnormalities was $7 \%$ (95\% confidence interval: 5-10\%). This updated meta-analysis provides new evidence to support the use of array-based comparative genomic hybridization in investigating patients with learning disability and congenital anomalies in whom conventional cytogenetic tests have proven negative. However, given that this technology also identifies false positives at a similar rate to causal variants, caution in clinical practice should be advised. Genet Med 2009:11(3):139-146.
\end{abstract}

Key Words: learning disability, mental retardation, array-based comparative genomic hybridization, microarrays, genetic testing

earning disability (LD) or mental retardation, is a significant Limpairment of the cognitive and adaptive functions, with onset before the age of 18 years ${ }^{1,2}$; other common terms are learning difficulty, intellectual disability, developmental delay, impaired cognition, and mental handicap. LD is a common condition affecting $1-3 \%$ of individuals worldwide, ${ }^{3}$ with genetic factors estimated to be the main cause in around half of all patients with severe LD and around $15 \%$ of patients with mild LD. ${ }^{4}$ The past decade has seen advances in genetics research highlighting the importance of genetic factors and in particular genomic imbalance in the etiology of LD. This has led to

From the ${ }^{1} \mathrm{MRC}$ Biostatistics Unit, University of Cambridge, Cambridge, United Kingdom; ${ }^{2}$ Department of Public Health and Primary Care, University of Cambridge, Cambridge, United Kingdom; ${ }^{3} \mathrm{PHG}$ Foundation, Strangeways Research Laboratory, Cambridge, United Kingdom; and ${ }^{4}$ Department of Medical Genetics, Cambridge University Hospitals NHS Trust, United Kingdom.

Dr. Gurdeep S. Sagoo, PHG Foundation, Strangeways Research Laboratory, Worts Causeway, Cambridge CB1 8RN, UK. E-mail: gurdeep.sagoo@srl. cam.ac.uk

Disclosure: The authors declare no conflict of interest.

Submitted for publication September 15, 2008

Accepted for publication November 11, 2008.

DOI: $10.1097 /$ GIM.0b013e318194ee8f improved diagnostic capability and, by providing a diagnosis, improving the welfare of patients and their families. ${ }^{5}$

Clinical assessment of children with LD typically involves examination by a pediatrician followed by appropriate biochemical and hematological tests as well as chromosomal tests and other molecular genetic tests. Existing cytogenetic tests involve a karyotype analysis followed by fluorescent in situ hybridization or multiplex ligation-dependent probe amplification, which can both identify submicroscopic chromosomal deletions and even single gene deletions located on specific chromosomes. ${ }^{6} \mathrm{~A}$ new method of analysis, array-based comparative genomic hybridization (array CGH), is increasingly being used routinely in patients with $\mathrm{LD}$, in addition to existing cytogenetic techniques when such tests prove negative. ${ }^{7,8}$

Array CGH identifies copy-number variations (either amplifications or deletions) across the entire genome at high resolution. ${ }^{7}$ The technology combines fluorescence techniques with the microarray platform and allows the comparison of DNA content in two differentially labeled genomes, a test genome (patient), and a reference genome (control). The microarray platform also allows the use of thousands of individual DNA sequences from throughout the genome, providing precise information in a single experiment about the locations of any identified aberrations. Array CGH has many advantages over conventional cytogenetic techniques in that it can provide rapid genome-wide assessments at a high resolution $(\leq 1 \mathrm{Mb})$ and precise location information linked to physical and genetic maps of the human genome. It can also detect single-copy gains and losses across whole chromosomes (including telomeric regions and prespecified chromosomal regions). However, balanced translocations cannot be detected. Another drawback is the potential for identifying novel copy number variants that may not be responsible for the patient's LD. ${ }^{9,10}$

The clinical significance of a copy number variant is usually determined either by observing whether the associated phenotype segregates along with the variant within a family, the rearrangement being already associated with a recognizable phenotype, or by whether the measured size of the variant is so large that it is unlikely to be without a phenotypic consequence. Causality is concluded when any of these occurs. Variants are considered benign (noncausal) if a phenotypically normal parent carries the same variant, although care must be taken to ensure that the breakpoints of the variant do not differ in the patient or parent because such a difference could be clinically relevant. Small de novo variants of unclear clinical significance are also identified, where neither parent carries the variant when the variant has not previously been associated with the phenotype in question.

In 2007, we reported that there was insufficient evidence to recommend the introduction of this test as a routine addition to current cytogenetic analysis although it could be helpful in 
Table 1 Identified studies and their characteristics

\begin{tabular}{|c|c|c|c|c|c|}
\hline Author (year) & Country & Patients & Setting & Controls & $\begin{array}{c}\text { Array } \\
\text { methods/resolution }\end{array}$ \\
\hline Vissers et al. (2003) & $\begin{array}{l}\text { Netherlands and the } \\
\text { United States }\end{array}$ & $\begin{array}{l}\text { Patients with MR and additional } \\
\text { dysmorphisms, scoring } 3 \\
\text { points or more on the de } \\
\text { Vries checklist }\end{array}$ & $\begin{array}{l}\text { Genetics } \\
\text { service }\end{array}$ & $\begin{array}{l}\text { Four normal healthy } \\
\text { blood donors }(2 \mathrm{M} \text {, } \\
2 \mathrm{~F})\end{array}$ & $1 \mathrm{Mb}$ array \\
\hline $\begin{array}{l}\text { Shaw-Smith et al. } \\
\text { (2004) }\end{array}$ & UK, France & $\begin{array}{l}\text { Moderate to severe MR, } \\
\text { nonconsanguineous, with at } \\
\text { least one clinical criterion } \\
\text { (out of four) }\end{array}$ & $\begin{array}{l}\text { Genetics } \\
\text { service }\end{array}$ & $\begin{array}{l}\text { Pooled DNA from } \\
\text { normal people } 20 \mathrm{M} \text {, } \\
20 \mathrm{~F}\end{array}$ & $1 \mathrm{Mb}$ array \\
\hline de Vries et al. (2005) & Netherlands & $\begin{array}{l}\text { MR, negative for karyotyping } \\
\text { and MLPA. Scored by a } \\
\text { checklist of clinical criteria } \\
(0-10)\end{array}$ & $\begin{array}{l}\text { Genetics } \\
\text { service }\end{array}$ & 72 parents of the cases & $\begin{array}{l}\text { Tiling resolution } \\
\text { whole genome } \\
\text { array }\end{array}$ \\
\hline $\begin{array}{l}\text { Schoumans et al. } \\
\text { (2005) }\end{array}$ & Sweden & $\begin{array}{l}\text { Mild to severe MR, with } \\
\text { phenotype suggestive of } \\
\text { chromosomal origin, i.e., } \\
\text { dysmorphism, malformations, } \\
\text { and/or family history, scoring } \\
\text { at least } 3 \text { points on the de } \\
\text { Vries checklist }\end{array}$ & $\begin{array}{l}\text { Genetics } \\
\text { service }\end{array}$ & $\begin{array}{l}\text { Reference DNA of a } \\
\text { pool of } 10 \text { normal } \\
\text { individuals }\end{array}$ & $1 \mathrm{Mb}$ array \\
\hline Menten et al. (2006) & Belgium & $\begin{array}{l}\text { Idiopathic MR with multiple } \\
\text { congenital anomalies }\end{array}$ & $\begin{array}{l}\text { Genetics } \\
\text { service }\end{array}$ & $\begin{array}{l}\text { Other patients in the } \\
\text { cohort }\end{array}$ & $1 \mathrm{Mb}$ array \\
\hline Miyake et al. (2006) & Japan & $\begin{array}{l}\text { Idiopathic MR with some } \\
\text { dysmorphic features }\end{array}$ & Various & $\begin{array}{l}2(1 \mathrm{M}, 1 \mathrm{~F}) \text { negative } \\
\text { and } 1 \text { positive control }\end{array}$ & Targeted array \\
\hline $\begin{array}{l}\text { Rosenberg et al. } \\
\text { (2006) }\end{array}$ & $\begin{array}{l}\text { Netherlands, Brazil, } \\
\text { and UK }\end{array}$ & $\begin{array}{l}\text { Mild to severe MR, with } \\
\text { cranial/facial dysmorphisms } \\
\text { and at least one additional } \\
\text { congenital abnormality. } \\
\text { Family history and } \\
\text { consanguinity were not } \\
\text { considered }\end{array}$ & $\begin{array}{l}\text { Genetics } \\
\text { Service }\end{array}$ & $\begin{array}{l}100 \text { control observations } \\
\text { for each chromosome } \\
\text { pair }\end{array}$ & $1 \mathrm{Mb}$ array \\
\hline Sharp et al. (2006) & $\begin{array}{l}\text { UK and the United } \\
\text { States }\end{array}$ & $\begin{array}{l}\text { Idiopathic MR with or without } \\
\text { associated dysmorphism or } \\
\text { congenital anomalies with } \\
\text { normal G-banded karyotypes }\end{array}$ & Various & $\begin{array}{l}316 \text { controls from } \\
\text { various populations } \\
\text { such as European, } \\
\text { sub-Saharan African, } \\
\text { Chinese, and Japanese }\end{array}$ & Targeted array \\
\hline Aradhya et al. (2007) & The United States & $\begin{array}{l}\text { Developmental delay or MR, } \\
\text { a normal high-resolution } \\
\text { karyotype and at least one of } \\
\text { the following criteria: } \\
\text { dysmorphic features, } \\
\text { congenital anomalies, or } \\
\text { growth retardation }\end{array}$ & $\begin{array}{l}\text { Genetics } \\
\text { service }\end{array}$ & $\begin{array}{l}\text { One male and one } \\
\text { female control } \\
\text { reference DNA, } \\
\text { purchased from } \\
\text { Promega }\end{array}$ & $\begin{array}{l}\text { Oligonucleotide-array } \\
\text { CGH with } 35 \mathrm{k} \\
\text { resolution }\end{array}$ \\
\hline Baris et al. (2007) & The United States & $\begin{array}{l}\text { Global developmental delay or } \\
\text { MR, facial dysmorphism, and } \\
\text { multiple congenital anomalies } \\
\text { with normal chromosomal } \\
\text { analysis }\end{array}$ & $\begin{array}{l}\text { Genetics } \\
\text { service }\end{array}$ & $\begin{array}{l}50 \text { phenotypically } \\
\text { normal individuals } \\
\text { ( } 25 \text { males, } 25 \\
\text { females) and } 36 \\
\text { patients with known } \\
\text { chromosomal } \\
\text { abnormalities }\end{array}$ & $1 \mathrm{Mb}$ array \\
\hline Baross et al. (2007) & The United States & $\begin{array}{l}\text { Moderate to severe MR with at } \\
\text { least one of the following } \\
\text { additional clinical features: } \\
\text { one major malformation, } \\
\text { microcephaly, abnormal } \\
\text { growth, or multiple minor } \\
\text { anomalies }\end{array}$ & $\begin{array}{l}\text { Genetics } \\
\text { Service }\end{array}$ & $\begin{array}{l}\text { Both unaffected parents } \\
\text { and } 10 \text { unaffected } \\
\text { siblings from } 10 \\
\text { families as negative } \\
\text { controls. Within-trio } \\
\text { comparisons, } 50 \\
\text { mothers with an MR } \\
\text { child, all } 214 \text { parents } \\
\text { and } 106 \text { individuals } \\
\text { from Affymetrix used } \\
\text { as reference set }\end{array}$ & $100 \mathrm{k}$ array \\
\hline
\end{tabular}


Table 1 (Continued)

\begin{tabular}{|c|c|c|c|c|c|}
\hline Author (year) & Country & Patients & Setting & Controls & $\begin{array}{c}\text { Array } \\
\text { methods/resolution }\end{array}$ \\
\hline Engels et al. (2007) & Germany & $\begin{array}{l}\text { Idiopathic MR with or without } \\
\text { congenital anomalies and a } \\
\text { median de Vries checklist } \\
\text { score of } 3 \text {. Normal G-banded } \\
\text { karyotypes were observed } \\
\text { with subtelomeric } \\
\text { chromosome aberrations } \\
\text { excluded by FISH }\end{array}$ & $\begin{array}{l}\text { Genetics } \\
\text { Service }\end{array}$ & $\begin{array}{l}\text { Sex-matched pooled } \\
\text { DNA from } 10 \text { healthy } \\
\text { male or female } \\
\text { controls }\end{array}$ & $\begin{array}{l}\text { I Mb array } \\
\text { supplemented with } \\
\text { additional } 3000 \\
\text { gene and region } \\
\text { specific BAC } \\
\text { clones increasing } \\
\text { resolution to } 0.5 \\
\mathrm{Mb}\end{array}$ \\
\hline Fan et al. (2007) & The United States & $\begin{array}{l}\text { MR or developmental delay } \\
\text { with two or more additional } \\
\text { clinical features such as } \\
\text { prenatal or postnatal growth }\end{array}$ & $\begin{array}{l}\text { Genetics } \\
\text { Service }\end{array}$ & $\begin{array}{l}\text { Seven normal males and } \\
\text { seven normal females } \\
\text { used as reference } \\
\text { DNA, purchased from }\end{array}$ & $\begin{array}{l}\text { Oligonucleotide-array } \\
\mathrm{CGH} \text { with } 30-35 \mathrm{k} \\
\text { resolution }\end{array}$ \\
\hline
\end{tabular}
retardation, dysmorphism, or malformations, and had a score of 3 or greater using the de Vries checklist

Lu et al. (2007) The United States Developmental delay and/or

The United States and "abroad"

Shen et al. (2007)

The United States

Thuresson et al. (2007)

Wagenstaller et al. (2007)

Pickering et al. (2008) MR, dysmorphic features, multiple congenital anomalies, seizure disorders and autistic or other behavioral abnormalities. Patients with known abnormal cytogenetic results were excluded

Developmental delays, MR, seizures, and various congenital anomalies. Mostly normal genetic studies including karyotype, subtelomere FISH, locusspecific FISH, and/or molecular studies for fragile $\mathrm{X}$ or other single gene disorders

Developmental delay, MR, dysmorphic features, or multiple congenital anomalies

Genetics service

Genetics Service

Reference DNA samples from one phenotypically normal male and one phenotypically normal female control with no detectable chromosomal aberrations by conventional karyotype analysis

Various

One negative control (normal diploid adult male) and one positive control (adult male with trisomy 21)

Each samples compared with either a 46,XY male or $46, \mathrm{XX}$ female reference sample purchased from Promega

Genetics Sex-matched pooled service DNA from either eight normal male or female blood donors dysmorphism with a normal karyotype from GTG-banding and subtelomeric rearrangements excluded by FISH

Mild or severe idiopathic MR, with normal G-banded chromosomes

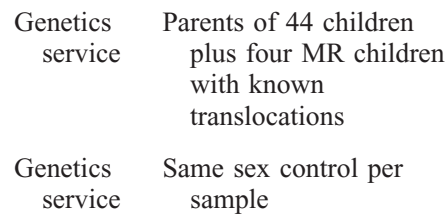

Oligonucleotide-array CGH with $35 \mathrm{k}$ resolution

Targeted array

Targeted array

I Mb array

100k array

$$
\begin{aligned}
& \text { Idiopathic developmental delay } \\
& \text { and MR with normal } \\
& \text { karyotype }
\end{aligned}
$$

MR, mental retardation; FISH, fluorescent in situ hybridisation; MLPA, multiplex ligation-dependent probe amplification; M, male; F, female; NS, not stated. 
certain circumstances. The subsequent increase in clinical use and the publication of 12 new studies evaluating array CGH has enabled us to update our previous findings.

\section{METHODS}

\section{Systematic review inclusion criteria}

Studies were included that used array CGH to identify genetic abnormalities in patients with LD and congenital anomalies, in whom conventional cytogenetic analysis proved negative. Both case series and cohort studies were eligible for inclusion.

\section{Search strategy and data extraction}

MEDLINE, EMBASE, and Web of Science databases were searched during March 2008 with both free text and MeSH terms using the strategy previously outlined, ${ }^{11}$ appropriately modified for the specific database. No language or other search restrictions were imposed and reference lists of primary studies were checked for additional references. Two reviewers (G.S.S. and A.S.B.) independently extracted data using the forms used in our first review. ${ }^{11}$ Reviewers compared results and resolved any differences through discussion. Where there were multiple publications of the same study, we extracted data from each publication and identified the most complete and up-to-date information.

\section{Assessment of study quality}

The following quality indicators were assessed: (1) clear description of the setting and study population; (2) whether criteria used for patient selection were clearly described; (3) evidence of appropriate pretesting with karyotyping, fluorescent in situ hybridization or telomere tests; (4) whether control samples were included, and if so, described clearly; (5) description of the array CGH platform, software, and assay process; (6) description of steps to identify and exclude known copy number polymorphisms using genome databases; (7) appropriate follow-up testing; and (8) clear description of the process of interpretation of array $\mathrm{CGH}$ results.

\section{Statistical analysis}

Diagnostic yield was defined and calculated for each study as the number of patients who had variants detected by array CGH that were judged to be causal, divided by the total number of patients tested. False-positive yield was defined and calculated as the number of patients who had variants detected by array $\mathrm{CGH}$ that were judged to be noncausal or of unknown significance, divided by the total number of patients tested. Metaanalyses were conducted on the scale of the logit of these proportions. The number needed to test to obtain one patient with a causal variant was estimated as the inverse of the diagnostic yield.

Table 2 Genetic abnormalities identified by array CGH in idiopathic learning disability and congenital anomalies

\begin{tabular}{|c|c|c|c|c|c|c|}
\hline Author (year) & Resolution & Patients & $\begin{array}{l}\text { Patients with } \\
\text { noncausal } \\
\text { abnormality }\end{array}$ & $\begin{array}{c}\text { False-positive } \\
\text { yield (\%) }\end{array}$ & $\begin{array}{l}\text { Patients with } \\
\text { casual } \\
\text { abnormality }\end{array}$ & Diagnostic yield (\%) \\
\hline Vissers et al. (2003) & $1 \mathrm{Mb}$ & 20 & 1 & 5.0 & 2 & 10.0 \\
\hline Shaw-Smith et al. (2004) & $1 \mathrm{Mb}$ & 50 & 5 & 10.0 & 7 & 14.0 \\
\hline de Vries et al. (2005) & $50 \mathrm{~Kb}$ & 100 & 5 & 5.0 & 10 & 10.0 \\
\hline Schoumans et al. (2005) & $1 \mathrm{Mb}$ & 41 & $\mathrm{NS}^{a}$ & $\mathrm{NS}^{a}$ & 4 & 9.8 \\
\hline Menten et al. (2006) & $1 \mathrm{Mb}$ & 140 & 9 & 6.4 & 19 & 13.6 \\
\hline Miyake et al. (2006) & $1.4 \mathrm{Mb}$ & 30 & 20 & 66.7 & 5 & 16.7 \\
\hline Rosenberg et al. (2006) & $1 \mathrm{Mb}$ & 81 & 7 & 8.6 & 13 & 16.0 \\
\hline Sharp et al. (2006) & Targeted & 290 & 7 & 2.4 & 16 & 5.5 \\
\hline Aradhya et al. (2007) & $35 \mathrm{~Kb}$ & 20 & 3 & 15.0 & 7 & 35.0 \\
\hline Baris et al. (2007) & $1 \mathrm{Mb}$ & 234 & 12 & 5.1 & 13 & 5.6 \\
\hline Baross et al. (2007) & $30 \mathrm{~Kb}$ & 100 & 1 & 1.0 & 11 & 11.0 \\
\hline Engels et al. (2007) & $0.5 \mathrm{Mb}$ & 60 & 1 & 1.7 & 6 & 10.0 \\
\hline Fan et al. (2007) & $30-35 \mathrm{~Kb}$ & 100 & 1 & 1.0 & 15 & 15.0 \\
\hline Lu et al. (2007) & Targeted & 2444 & 231 & 9.5 & 171 & 7.0 \\
\hline Shaffer et al. (2007) & Targeted & 8789 & 445 & 5.1 & 604 & 6.9 \\
\hline Shen et al. (2007) & $35 \mathrm{~Kb}$ & 211 & 9 & 4.3 & 16 & 7.6 \\
\hline Thuresson et al. (2007) & $1 \mathrm{Mb}$ & 48 & 2 & 4.2 & 3 & 6.3 \\
\hline Wagenstaller et al. (2007) & $23.6 \mathrm{~Kb}$ & 67 & 13 & 19.4 & 11 & 16.4 \\
\hline Pickering et al. (2008) & $1 \mathrm{Mb}$ & 1101 & 47 & 4.3 & 86 & 7.8 \\
\hline
\end{tabular}

${ }^{a}$ Not stated: a total of 151 copy number polymorphisms (CNP) detected in the cohort; number of patients with CNPs not stated. 
Before meta-analysis, inconsistency of findings (heterogeneity) was tested using standard $\chi^{2}$ methods and by using the $I^{2}$ statistic, which describes the proportion of total variation in estimates that is due to heterogeneity rather than random error. ${ }^{12}$ Funnel plots and associated statistical tests ${ }^{13,14}$ were used to assess assumptions involved in meta-analysis and to explore the relationship between precision and magnitude of estimates. The meta-analysis was conducted using a random-effects model, assuming that heterogeneity can be represented by a normal distribution for the underlying effects. Meta-regression was used to investigate variation across studies using the following studylevel covariates: study sample size $(<100,100-499$, $\geq 500)$, array resolution $(<1 \mathrm{Mb}, 1 \mathrm{Mb}$, targeted array), patient source (genetic laboratory, clinical setting), patient source (Europe, North America, mixed, Japan), and use of de Vries clinical score (yes, no).

\section{RESULTS}

\section{Study characteristics}

Nineteen primary studies, ${ }^{6,15-32}$ incorporating a total of 13,926 subjects, were identified that met the inclusion criteria (Table 1). Twelve studies were identified since the publication of our previous meta-analysis. ${ }^{21-32}$ Seven studies were con- ducted on patients based in the United States, ${ }^{21-23,25,28,31,32}$ seven in Europe, 6,15,17,18,24,29,30 four using patients from multiple sources based in North America, South America, or Europe ${ }^{19,20,26,27}$ and one in Japan. ${ }^{16}$ All studies included sampling of control DNA as part of their protocol. Seven studies used a $1 \mathrm{Mb}$ array for investigating the whole genome, 6,15,18-20,22,29 four used a targeted array, 16,26,27,31 three used an oligonucleotide array with $30-35 \mathrm{k}$ resolution, ${ }^{21,25,28}$ two studies used a $100-\mathrm{k}$ array, ${ }^{23,30}$ one used a tiling BAC array, ${ }^{17}$ one study used both a targeted array and a 1-Mb array, ${ }^{32}$ and another used a $1-\mathrm{Mb}$ array supplemented with an additional 3000 gene and region-specific BAC clones increasing the resolution to 0.5 Mb. ${ }^{24}$ Control samples varied from 2 to 316 normal people, whereas Menten et al. ${ }^{15}$ used samples from other patients in the cohort as controls. There was some variation in the clinical criteria for patient selection and testing, with some investigators using the de Vries clinical severity score. ${ }^{17}$

\section{Test performance}

The combined diagnostic yield of causal genetic abnormalities in the 19 studies was $10 \%$ (95\% confidence interval [CI]: $8 \%, 12 \%$ ) (Table 2, Fig. 1). There was evidence of heterogeneity $\left(\chi^{2}=63.75, P<0.001 ; I^{2}=72 \%, 95 \%\right.$ CI: $\left.55 \%, 82 \%\right)$. In meta-regression analysis, the study level characteristics of

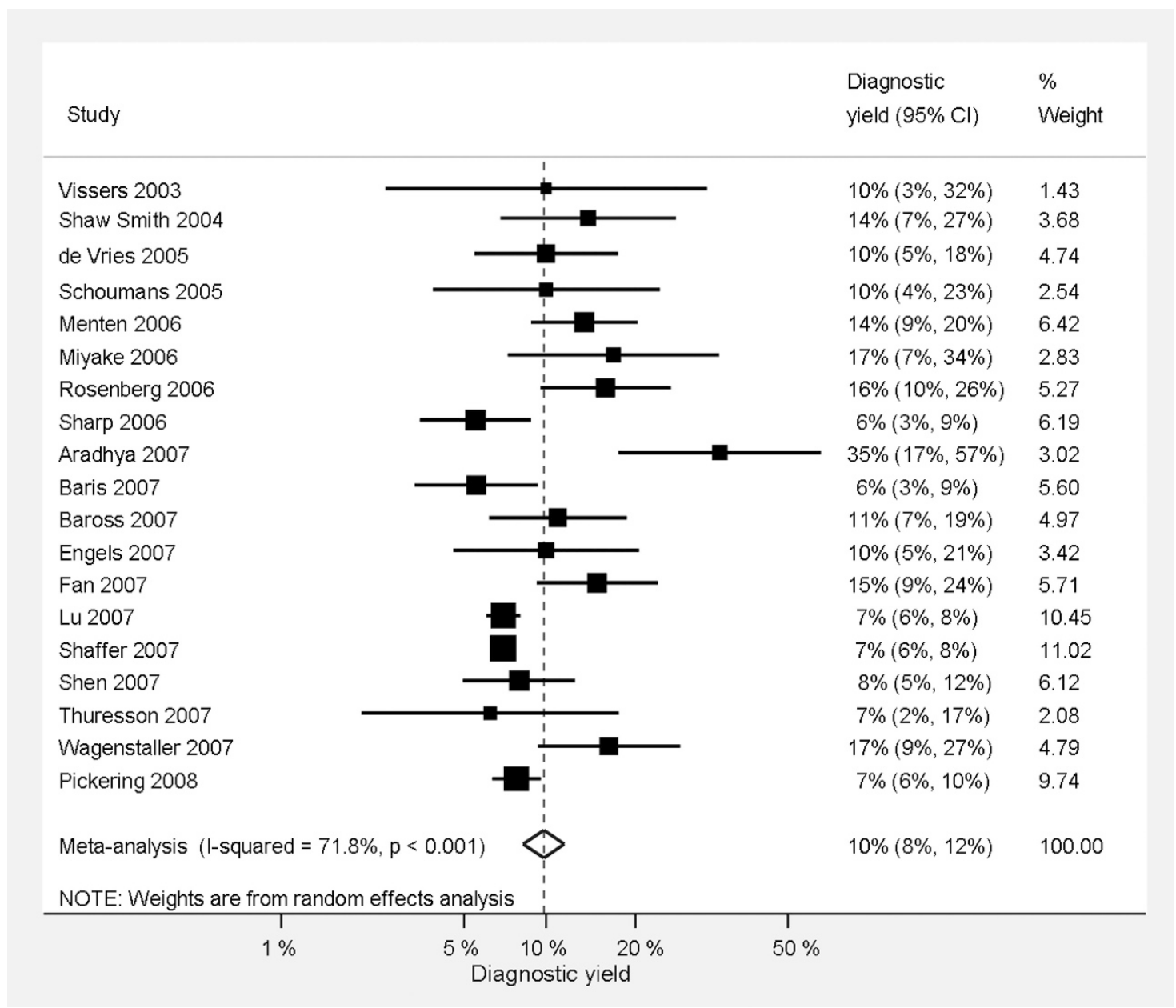

Fig. 1. Random-effects meta-analysis of diagnostic yield from array-based CGH in patients with learning disability and congenital anomalies. $\mathrm{Cl}$, confidence interval. The diamond represents the overall estimate of diagnostic yield. 


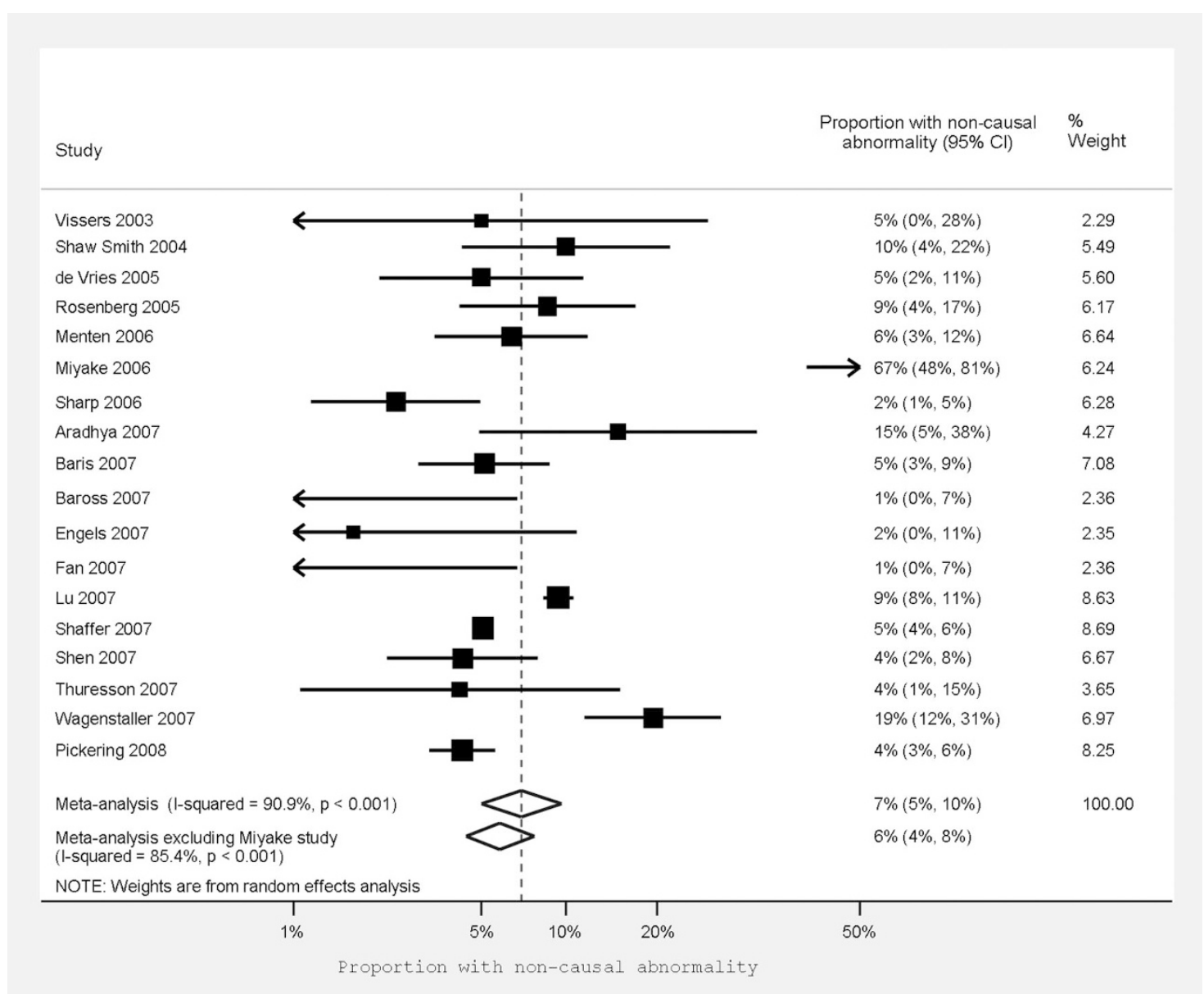

Fig. 2. Random-effects meta-analysis of false-positive yield from array-based CGH in patients with learning disability and congenital anomalies. $\mathrm{Cl}$, confidence interval. The upper diamond represents the overall estimate of false-positive yield based on 18 studies. The lower diamond represents the overall estimate of false-positive yield based on 17 studies having excluded the study by Miyake et al. ${ }^{16}$

sample size (explaining $72 \%$ of the between-study variance of logit proportions, $P=0.003)$ and array resolution $(50 \%$ of the variance, $P=0.007$ ) individually explain much of this heterogeneity. Studies in which array resolution was less than $1 \mathrm{Mb}$ had a combined diagnostic yield of 14\% (95\% CI: 9\%, 20\%). Funnel plot asymmetry was observed with the possibility of an excess of smaller studies with striking results (Egger's test $P=$ 0.002). The combined diagnostic yield of the three largest studies ( $>1000$ participants each) was 7\% (95\% CI: 7\%, 8\%). The number needed to test to identify one new causal variant was 10 (95\% CI: $8 \%, 13 \%)$.

The proportion of noncausal variants detected by array CGH ranged from 1 to $67 \%$. A meta-analysis of the 18 studies with available data (excluding Schoumans et al. ${ }^{18}$ ) gives a combined false-positive yield of 7\% (95\% CI: 5\%, 10\%) (Table 2, Fig. 2). There was strong evidence of heterogeneity $\left(\chi^{2}=187.29, P<\right.$ $0.001 ; I^{2}=91 \%, 95 \%$ CI: $\left.87 \%, 94 \%\right)$. Sample size accounted for $24 \%$ of this heterogeneity although this was not statistically significant $(P=0.136)$. We did not observe funnel plot asymmetry from either visual inspection or test statistics (Egger's test $P=0.796$ ). In our previous review, we excluded the study by Miyake et al. ${ }^{16}$ because it distorted the false-positive range with its large false-positive value (the other studies ranged 1-19\%) and relatively large contribution (because of the small number of studies included). With the subsequent increase in study number and sample size, the study by Miyake et al. ${ }^{16}$ contributes less to the overall false-positive yield (a weight of $6 \%$ under random effects), and a meta-analysis of the remaining seventeen studies gives a combined false-positive yield of $6 \%$ (95\% CI: 4\%, 8\%) (Fig. 2).

\section{DISCUSSION}

This updated review was based on more than twice the number of studies in our previous review, ${ }^{11}$ with a 30 -fold increase in the number of subjects from 462 to 13,926 (Table 3). Because of the increase in the number of studies and participants, our estimates of average diagnostic yield are much more precise (current review 10\%, 95\% CI: $8 \%, 12 \%$ versus previous review 13\%, 95\% CI: 10\%, 17\%; Table 3). The increased number of studies also enabled us to investigate study heterogeneity.

Much of the heterogeneity observed in our analysis of diagnostic yield could be attributed to sample size and array resolution. Our analysis of array resolution suggests arrays with a resolution of less than $1 \mathrm{Mb}$ have a greater diagnostic yield 
Table 3 Comparison of findings of our present updated meta-analyses with our previous meta-analyses ${ }^{11}$

\begin{tabular}{|c|c|c|c|c|c|c|c|}
\hline & \multicolumn{3}{|c|}{ Diagnostic yield } & \multicolumn{3}{|c|}{ False-positive yield } & \multirow[b]{2}{*}{ Number needed to test } \\
\hline & No. studies & No. patients & Diagnostic yield & No. studies & No. patients & False-positive yield & \\
\hline Previous review ${ }^{11}$ & 7 & 462 & $13 \%(95 \%$ CI: $10 \%, 17 \%)$ & 5 & 391 & $7 \%(95 \%$ CI: $5 \%, 10 \%)$ & 8 (95\% CI: 6\%, 10\%) \\
\hline Present review & 19 & 13,926 & $10 \%$ (95\% CI: $8 \%, 12 \%)$ & $17^{a}$ & 13,855 & $6 \%$ (95\% CI: 4\%, 8\%) & 10 (95\% CI: 8\%, 13\%) \\
\hline
\end{tabular}

${ }^{a}$ False-positive yield result presented with the exclusion of the study by Miyake et al. ${ }^{16}$ to allow direct comparison with previous result.

(14\%, 95\% CI: 9\%, 20\%) although additional studies would be required to further improve precision. The relationship with sample size (larger yields in smaller studies) is compatible with several explanations. A key threat to literature-based reviews and meta-analyses is the possibility of reporting bias, such as a publication bias, which often manifests itself as an excess of smaller studies with more striking results. An alternative explanation could be that the larger studies involved patients with less severe LD, and hence with fewer genetic causes. However, the spectrum of patients tested appears to be similar, all studies having selected patients with LD and congenital anomalies. All selected patients also had negative results for conventional cytogenetic tests. The consistent use of a clinical severity score such as that employed by de Vries et al., ${ }^{17}$ along with stratification of data by such a clinical score, would allow the selection of patients who are most likely to benefit from evaluation of array CGH by clinical severity. Also, although 12 new studies were identified in this updated review, important differences in ethnicity of patients could not be investigated because of the identification of only a single study of Asian origin. This is an area in which further research is also warranted. This metaanalysis therefore provides direct evidence only for highly selected, mainly Western (European and North American) patients, using array CGH to identify patients previously undiagnosed by other tests.

Array CGH is able to identify causal genetic abnormalities in patients with LD and congenital anomalies, in whom previous conventional cytogenetic analysis has proven negative. However, it also identifies genetic abnormalities deemed to be noncausal or of unknown relevance (false positives) at a similar frequency. It remains to be seen how these noncausal variants should be viewed in practice and how such results should be communicated to patients. Nevertheless, our updated analysis in 19 studies shows that the false-positive yield is low $(7 \%, 95 \% \mathrm{CI}: 5 \%, 10 \%)$. Future studies should concentrate on trying to minimize the number of false positives being identified.

Databases such as DECIPHER (http://decipher.sanger.ac.uk) and ECARUCA (http://www.ecaruca.net) facilitate and expedite the identification of new disorders in clinical cytogenetics. Access to these databases allows the opportunity to identify overlapping phenotypic and genotypic features against the aggregated patient case reports. ${ }^{33}$ In addition to these databases, the Toronto Database of Genomic Variants (http://projects. tcag.ca/variation/project.html) provides comprehensive information regarding copy number variants identified as benign and unlikely to be pathogenic if identified in a patient with LD and congenital anomalies. We would strongly encourage clinicians to use these online resources and to contribute identified copy number variants and validate existing genotypic and phenotypic data. The most commonly identified cytogenetic regions in the published literature include 1p36.3, 15q11-q12, and 22q11.2.26,31,32,34 These regions could be targeted for greater coverage in future array design to allow a more accurate estimation of the size and characteristics of any rearrangements identified.

The use of array CGH as part of the investigation of the child with LD is gaining considerable momentum as the costs of the technology decrease. Services in which there is limited cytogenetics capacity, such as many middle income countries, may also begin to use this technology as a first line diagnostic investigation. However, a continued evidence-based approach to evaluate array $\mathrm{CGH}$ within the clinical pathway will be important in considering how, when, and for which patients it should be incorporated into routine services. The results of this updated meta-analysis provide new evidence to support the routine use of array $\mathrm{CGH}$ in investigating patients with $\mathrm{LD}$ and congenital anomalies, in whom previous conventional cytogenetic analysis have proven negative. However, given that the technology also identifies false positives at a similar rate to causal variants, some caution in clinical practice is also required. In particular, at present a decision on the use of array $\mathrm{CGH}$ is the responsibility of a clinical geneticist who will be able to assess likely clinical utility and interpret results for the parents. Further, although this systematic review has provided additional information about the use of array CGH in a clinically selected group of patients where conventional cytogenetics is negative, findings cannot be extrapolated to an unselected group, where LD may be less severe and the likelihood of a genetic cause is less. The use of array CGH as a first line investigation in all patients with LD should therefore be further evaluated through large prospective studies.

\section{ACKNOWLEDGMENTS}

This review was supported by a research grant from the UKGTN held by the PHG Foundation. G.S.S. is funded by a research grant from the PHG Foundation held by the MRC Biostatistics Unit. A.S.B. is supported by a personal award from the National Institute for Health Research. J.P.T.H is supported by MRC Grant U.1052.00.011. The authors thank the investigators who coordinated the previous systematic review and meta-analysis: Drs. S. Subramonia-Iyer, R. Zimmern, M. Kroese, and P. Brice.

\section{REFERENCES}

1. Department of Health. Valuing people: a new strategy for learning disability for the 21st century. London: The Stationery Office, 2001

2. World Health Organisation. The ICD-10 classification of mental and behavioural disorders. Clinical descriptions and diagnostic guidlines. Geneva: World Health Organisation, 1992

3. Roeleveld N, Zielhuis GA, Gabreels F. The prevalence of mental retardation: a critical review of recent literature. Dev Med Child Neurol 1997;39:125-132.

4. Hagberg B, Kyllerman M. Epidemiology of mental retardation — a Swedish survey. Brain Dev 1983;5:441-449.

5. Knight SJ, Regan R. Idiopathic learning disability and genome imbalance. Cytogenet Genome Res 2006;115:215-224.

6. Shaw-Smith C, Redon R, Rickman L, et al. Microarray based comparative genomic hybridisation (array-CGH) detects submicroscopic chromosomal 
deletions and duplications in patients with learning disability/mental retardation and dysmorphic features. J Med Genet 2004;41:241-248.

7. Cheung SW, Shaw CA, Yu W, et al. Development and validation of a CGH microarray for clinical cytogenetic diagnosis. Genet Med 2005;7:422-432.

8. Yu W, Ballif BC, Kashork CD, et al. Development of a comparative genomic hybridization microarray and demonstration of its utility with 25 well-characterized 1p36 deletions. Hum Mol Genet 2003;12:2145-2152.

9. Iafrate AJ, Feuk L, Rivera MN, et al. Detection of large-scale variation in the human genome. Nat Genet 2004;36:949-951.

10. Sebat J, Lakshmi B, Troge J, et al. Large-scale copy number polymorphism in the human genome. Science 2004;305:525-528.

11. Subramonia-Iyer S, Sanderson S, Sagoo G, et al. Array-based comparative genomic hybridization for investigating chromosomal abnormalities in patients with learning disability: systematic review meta-analysis of diagnostic and false-positive yields. Genet Med 2007;9:74-79.

12. Higgins JP, Thompson SG, Deeks JJ, Altman DG. Measuring inconsistency in meta-analyses. BMJ 2003;327:557-560.

13. Begg CB, Mazumdar M. Operating characteristics of a rank correlation test for publication bias. Biometrics 1994;50:1088-1101.

14. Egger M, Davey SG, Schneider M, Minder C. Bias in meta-analysis detected by a simple, graphical test. BMJ 1997;315:629-634.

15. Menten B, Buysse K, Vandesompele J, et al. Identification of an unbalanced $\mathrm{X}$-autosome translocation by array $\mathrm{CGH}$ in a boy with a syndromic form of chondrodysplasia punctata brachytelephalangic type. Eur J Med Genet 2005; 48:301-309.

16. Miyake N, Shimokawa O, Harada N, et al. No detectable genomic aberrations by BAC array CGH in Kabuki make-up syndrome patients. Am J Med Genet A 2006;140:291-293.

17. de Vries BB, Pfundt R, Leisink M, et al. Diagnostic genome profiling in mental retardation. Am J Hum Genet 2005;77:606-616.

18. Schoumans J, Ruivenkamp C, Holmberg E, Kyllerman M, Anderlid BM, Nordenskjold M. Detection of chromosomal imbalances in children with idiopathic mental retardation by array based comparative genomic hybridisation (array-CGH). J Med Genet 2005;42:699-705.

19. Rosenberg C, Knijnenburg J, Bakker E, et al. Array-CGH detection of micro rearrangements in mentally retarded individuals: clinical significance of imbalances present both in affected children and normal parents. J Med Genet 2006;43:180-186.

20. Vissers LE, de Vries BB, Osoegawa K, et al. Array-based comparative genomic hybridization for the genomewide detection of submicroscopic chromosomal abnormalities. Am J Hum Genet 2003;73:1261-1270.

21. Aradhya S, Manning MA, Splendore A, Cherry AM. Whole-genome arrayCGH identifies novel contiguous gene deletions and duplications associated with developmental delay, mental retardation, and dysmorphic features. $\mathrm{Am} J$ Med Genet A 2007;143:1431-1441.

22. Baris HN, Tan WH, Kimonis VE, Irons MB. Diagnostic utility of array-based comparative genomic hybridization in a clinical setting. Am J Med Genet Part A 2007; 143:2523-2533.

23. Baross A, Delaney AD, Li HI, et al. Assessment of algorithms for high throughput detection of genomic copy number variation in oligonucleotide microarray data. BMC Bioinformatics 2007;8:368.

24. Engels H, Brockschmidt A, Hoischen A, et al. DNA microarray analysis identifies candidate regions and genes in unexplained mental retardation. Neurology 2007;68:743-750.

25. Fan YS, Jayakar P, Zhu H, et al. Detection of pathogenic gene copy number variations in patients with mental retardation by genomewide oligonucleotide array comparative genomic hybridization. Hum Mutat 2007;28:1124-1132.

26. Shaffer LG, Bejjani BA, Torchia B, Kirkpatrick S, Coppinger J, Ballif BC. The identification of microdeletion syndromes and other chromosome abnormalities: cytogenetic methods of the past, new technologies for the future. Am J Med Genet C Semin Med Genet 2007;145:335-345.

27. Sharp AJ, Hansen S, Selzer RR, et al. Discovery of previously unidentified genomic disorders from the duplication architecture of the human genome. Nat Genet 2006;38:1038-1042.

28. Shen Y, Irons M, Miller DT, et al. Development of a focused oligonucleotidearray comparative genomic hybridization chip for clinical diagnosis of genomic imbalance. Clin Chem 2007;53:2051-2059.

29. Thuresson AC, Bondeson ML, Edeby C, et al. Whole-genome array-CGH for detection of submicroscopic chromosomal imbalances in children with mental retardation. Cytogenet Genome Res 2007;118:1-7.

30. Wagenstaller J, Spranger S, Lorenz D, et al. Copy-number variations measured by single-nucleotide-polymorphism oligonucleotide arrays in patients with mental retardation. Am J Hum Genet 2007;81:768-779.

31. Lu X, Shaw CA, Patel A, et al. Clinical implementation of chromosomal microarray analysis: summary of 2513 postnatal cases. PLOS ONE 2007;2: e327.

32. Pickering DL, Eudy JD, Olney AH, et al. Array-based comparative genomic hybridization analysis of 1176 consecutive clinical genetics investigations. Genet Med 2008;10:262-266.

33. Van Vooren S, Coessens B, De Moor B, Moreau Y, Vermeesch JR. Array comparative genomic hybridization and computational genome annotation in constitutional cytogenetics: suggesting candidate genes for novel submicroscopic chromosomal imbalance syndromes. Genet Med 2007;9:642-649.

34. Shaffer LG, Kashork CD, Saleki R, et al. Targeted genomic microarray analysis for identification of chromosome abnormalities in 1500 consecutive clinical cases. J Pediatr 2006;149:98-102. 